\title{
Critically endangered mohashol, Tor tor: Present status and road to conservation in Bangladesh
}

\author{
MUHAMMAD SHALAH UDDIN KABIR ${ }^{1}$, MD. RAFIQUL ISLAM SARDER*, \\ MOHAMMAD MATIUR RAHMAN, MD. FAZLUL AWAL MOLLAH \\ AND MOHAMMAD ABU TAHER \\ Department of Fisheries Biology and Genetics \\ Bangladesh Agricultural University, Mymensingh 2202, Bangladesh \\ ${ }^{1}$ Department of Fisheries, Bangladesh \\ *Corresponding Author: rafiqulsarder@yahoo.com
}

\begin{abstract}
Mohashol, Tor tor is one of the most beautiful indigenous fish of Bangladesh. It is a globally acclaimed sport and table fish and distributed in many South and Southeast Asian countries. In the past Tor tor was reported to be available in some rivers of different parts of Bangladesh, but at present this species is very rarely found only in Someshwari, one of the transboundary rivers of Bangladesh. Illegal fishing practices, soil erosion and siltation, construction of flood control and drainage structures, excessive human intervention on this river for livelihood as well as climate change have been considered as the main causes to degrade the habitat of mohashol. Moreover, unscientific coal mining in Meghalaya has further aggravated the problem. Consequently, T. tor has been red listed as critically endangered fish in Bangladesh. Though few attempts have been made for conservation of $T$. putitora, the endangered $T$. tor did not get such due importance. So, it is the prime time to put our heads together to conserve this lucrative, aristocratic and iconic fish and to design an integrated conservation project under a multilateral agreement among the South Asian countries specially India, Bangladesh and Nepal as the initial step in this regard.

Keywords: Mohashol, Tor tor, Endangered, Conservation, Someshwari
\end{abstract}

\section{Introduction}

The critically endangered mohashol (Tor tor), commonly known as tor mahseer or tor barb, is one of the most beautiful endemic cyprinid fishes in Bangladesh. This fish may reach about $36 \mathrm{~cm}$ at maturity (Jha et al. 2018), but the maximum length of $200 \mathrm{~cm}$ has been recorded (Fishbase 2014). The fish is well armoured by their record large scales, each reaching up to $10 \mathrm{~cm}$ (3.9 in) in length (McGrouther 2006). They live in upstream, clear, running waters and often prefer stony, pebbly or rocky bottoms ( $\mathrm{Ng}$ 2004, Shrestha 1990 and 1997). Mohashol, is distributed in many South and Southeast Asian countries including India, Bangladesh, Pakistan, Nepal, Myanmar, Indonesia, Malaysia, Java, Laos, Afghanistan and South China (Rahman 1989, Menon 1992, Roberts 1993, Chen and Yang 2004). In the past, two mohashol species Tor tor and T. putitora were reported to be available in the hilly streams of Sylhet, Mymensingh, Netrokona, Dinajpur and Kaptai reservoir of Chittagong Hill Tracts in Bangladesh. In the recent past the availability of Tor tor was reported to be limited in the river Someshwari of Netrakona and the Kangsha of Mymensingh district of Bangladesh (Rahman 1989). At present Tor tor is very rarely found only in the Someshwari river of Bangladesh.

Mohashol have high demand as food item. They have an attraction to anglers as a sport fish and are potential candidate for aquaculture (Haque et al. 1995, Ingram et al. 2005, Ogale 2002). It is highly sought after as ornamental fish in the aquarium fish industry due to their attractive

https://doi.org/10.52168/bjf.2021.33.18 
colouration (Ng 2004). Vedas and Smrite, the epics of Hindu mythology, also consider Mohashol a privileged fish mentioning Brahmins used it to propitiate the souls of their deceased ancestors. Due to the large size, mohashol finds a place among the 20 'mega fishes' of the world (Stone 2007) and has often been called the world's hardest fighting fish (Trans World Fishing Team 1984). Mohashols are considered as 'The tiger or the king of freshwater rivers'. Early anglers in India considered mohashols better than hunting for the tiger. Edward James Corbett, the British hunter, tracker and naturalist called it "a sport fit for kings-'fishing for Mahseer" (Madras Courier 2018). Without any negative competition mohashol can be used in polyculture, cage culture and for river ranching with mrigal (Cirrhinus mrigala) and common carp (Cyprinus carpio) (Ogale 2002). In Bangladesh, typically mohashol is sold at 35-50 USD per kg depending on weight, which is 6-8 times higher than other cultured carp species due to its unique taste and appearance.

\section{Someshwari River, the existing habitat of Tor tor}

Someswari river, the habitat of mohashol, is one of the rivers which lost her golden past in respect of water flow, fish species diversity as well as aquatic biodiversity in recent years. In India this river is also known as Simsang river which is the longest river and cultural icon of Garo Hills of Meghalaya, one of the important hill states of North-East India. Someswari river originates in the Nokrek Peak (now declared as Nokrek Biosphere Reserve) and is located about 1412 meters above from the mean sea level (MSL). It lies $13 \mathrm{~km}$ Southeast of two faults and along with the Northern faults, the river flows towards the East for about $45 \mathrm{~km}$. It drains the hills between Tura and Arbela ranges and the valley of Rongdi. The river has a winding course. At first it flows in an East wide direction for about $75 \mathrm{~km}$ and then takes a turn towards the South and flows in a Southerly direction until it leaves the hills and enters the plains of Bangladesh (Sarma et al. 2009). In Bangladesh it flows through the Susang-Durgapur and other areas of Netrakona till it flows into the Kangsha river in Netrakona district (Fig.1). A branch of the river flows towards Kalmakanda and meets the Balia. Another branch of the river flows into the haor areas of Sunamganj district and flows into the Surma river. Before joining Kangsha river, it flows across the Bijoypur and Ranokhong from northern to southern Jaria-Jhanjyle through the Sibganj bazaar (West bank) and Durgapur Sadar (East bank).

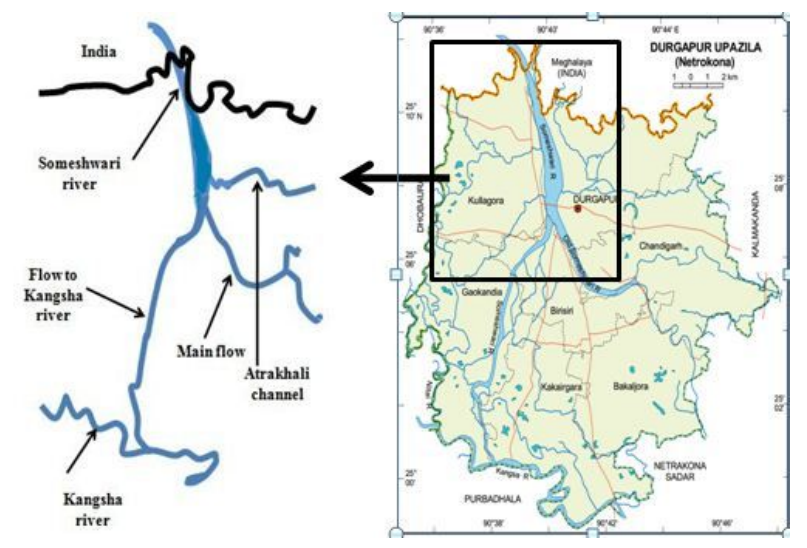

Fig. 1. Branches of the Someshwari, a transboundary river of Bangladesh. 
In November 1991, a small abandoned channel north of Durgapur with a flow direction towards the east was rejuvenated after 1990 (Alam 2004). This small meandering channel was locally named Atrakhali channel. However, except in rainy season there is no evidence of water flow in the main river and Atrakhali channel (Fig. 2).
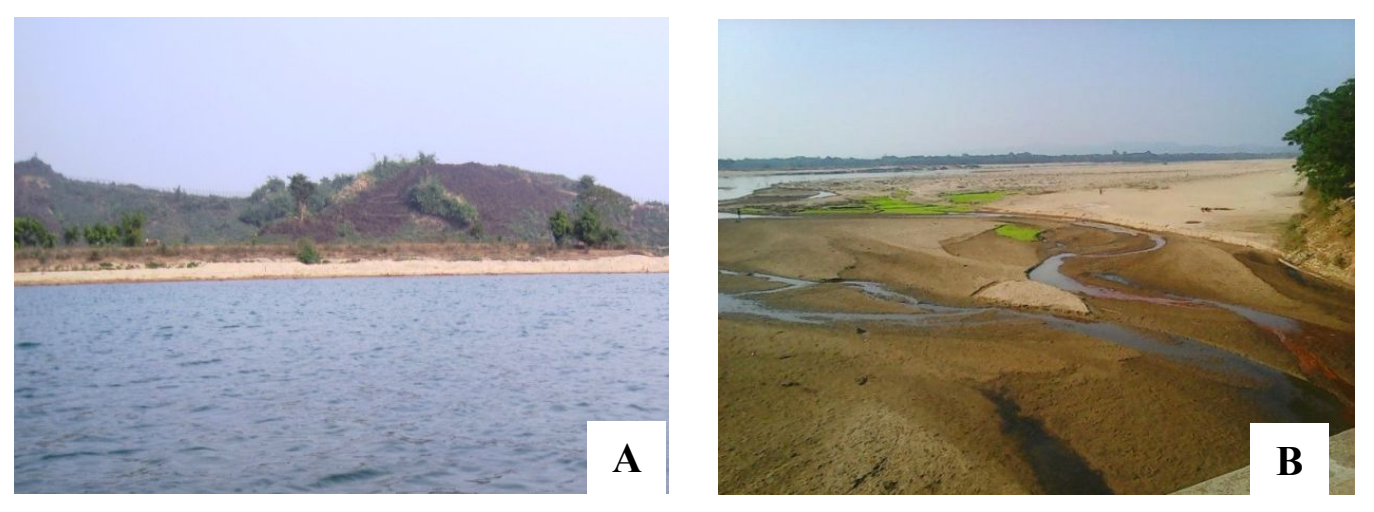

Fig. 2. Scenario of Someshwari river in early rainfall (A) and in dry season (B).

\section{Present status of mohashol, Tor tor}

During rainy season, fishers used to collect the mohashol from Someshwari river and its adjacent floodplain by operating various fishing gears locally called khorajal, dharma jal, jhakijal, the lajal and rear them in ponds with other carp species. A major portion of captured mohashol attains $100-250 \mathrm{~g}$, though fish weighing of 3.0-4.0 kg are also trapped very rarely by fishers. After two to three years of rearing, fishers sell the fish at high price to affluent customers. But due to climate change and many other factors, the availability of mohashol is decreasing day by day in Bangladesh. According to the fishers on the bank of the Someshwari river, 6-7 mohashol species are available, but in Bangladesh two species i.e., T. tor and $T$. putitora are found. The rural people of Durgapur called the mohashol as mashol and believe that it can make any impossible to possible. Moreover, it has tremendous demand as gift.

The data on availability of mohashol and its habitat i.e. the river Someshwari is limited. Monitoring population performance of mohashol in River Someshwari is problematic due to the logistical difficulties as well as to reach to the breeding and nursery grounds of the fish towards upstream due to border crossing restriction imposed from both Bangladesh and Indian Governments. Thus, there is a paucity of available data to access the current status and vulnerability of stocks in this river. Chakraborty and Mirza (2010) studied the aquatic resources of Someshwari river and gave a scenario of the stocks of fish by obtaining data through market survey and interaction with local fishers. This study along with personal interview and Focus Group Discussion (FGD) with local fisher folk at Shibganj bazaar, Atrakhali, Kumargata, Mou, Teribazaar, and Ranikhong point of the Someshwari river and with the Upazila Fisheries Officer, Durgapur, Netrakona (personal communication) provided information about the availability of Tor tor and Tor putitora which are shown in Table I. 
CRITICALLY ENDANGERED MOHASHOL, TOR TOR : PRESENT STATUS AND ROAD TO CONSERVATION

Table I. Year-wise catch of $T$. tor and T. putitora

\begin{tabular}{|c|c|c|c|}
\hline Year & T. tor $(\mathrm{mt})$ & T. putitora $(\mathrm{mt})$ & Reference \\
\hline 2001 & 0.08 & 0.06 & \multirow[t]{5}{*}{ Chakraborty and Mirza (2010) } \\
\hline 2002 & 0.04 & 0.03 & \\
\hline 2003 & 0.02 & 0.01 & \\
\hline 2004 & 0.01 & 0.00 & \\
\hline 2005 & 0.01 & 0.00 & \\
\hline 2006 & 0.015 & 0.005 & \multirow{10}{*}{$\begin{array}{l}\text { Interview and Focus Group } \\
\text { Discussion (FGD) with local } \\
\text { fisher folk at Shibganj bazaar, } \\
\text { Atrakhali, Kumargata, Mou, } \\
\text { Teribazaar, and Ranikhong } \\
\text { point of the Someshwari river, } \\
\text { and Upazilla Fisheries Officer, } \\
\text { Durgapur, Netrakona } \\
\text { (personal communication) }\end{array}$} \\
\hline 2007 & 0.008 & 0.006 & \\
\hline 2008 & 0.01 & 0.00 & \\
\hline 2009 & 0.02 & 0.00 & \\
\hline 2010 & 0.015 & 0.005 & \\
\hline 2011 & 0.012 & 0.01 & \\
\hline 2012 & 0.005 & 0.005 & \\
\hline 2013 & 0.004 & 0.003 & \\
\hline 2014 & 0.003 & 0.00 & \\
\hline 2015 & 0.008 & 0.002 & \\
\hline
\end{tabular}

\section{Causes of depletion of mohashol, Tor tor}

In the globe one third of the freshwater fishes are becoming threatened and some of the mare in the verge of extinction (Dudgeon, 2012). Freshwater fishes are increasingly threatened by a range of factors, including habitat loss, over-exploitation and biological invasions (Dudgeon 2012, Gozlan et al. 2005). Over-exploitation, water pollution, flow modification, destruction or degradation of habitat, and invasion by exotic species can be grouped under five interacting categories as major threats to freshwater biodiversity, with global scale environmental changes superimposed upon them all (Dudgeon et al. 2006). These globally escalating threats have led to freshwater biodiversity falling into a state of crisis (Vorosmarty et al. 2010) and becoming more imperiled than its marine or terrestrial counterparts (Strayer and Dudgeon 2010). In South Asia, population growth and its related development has led to heavily degraded water quality with threats such as deforestation leading to sedimentation, poor wastewater treatment, agricultural and industrial expansion and pollution, huge levels of water abstraction, and construction of dams leading to altered flow regimes and saltwater intrusion (Babel and Wahid 2008). Disturbances resulting from rapid growth of population coupled with lack of proper management policies, water management programs including the large scale extraction of water for irrigation and the construction of water barrages and dams, over-exploitation of fish using harmful fishing gears and system (fishing by dewatering, poisoning, explosives), road communication, siltation of water bodies by natural process, the unregulated introduction of alien fish species and pollution from industry and agrochemicals are the main causes of depletion of open water fish stocks in Bangladesh (Hossain 2014). For these reasons many fishes are either endangered or critically endangered and some of them have already been extinct from the waters of Bangladesh (IUCN 2015). 
The downstream of the Someshwari river system is heavily silted that reduces the rate of water flow and causes habitat degradation. Like other floodplains, the feeding and breeding grounds of fishes in and around the Someshwari river have been reducing drastically from various human interferences. Indiscriminate destructive fishing practices, soil erosion, siltation caused by large scale sand and coal particle collection, construction of flood control and drainage structures and agro-chemicals have caused havoc to the aquatic biodiversity in this river (Fig. 3).

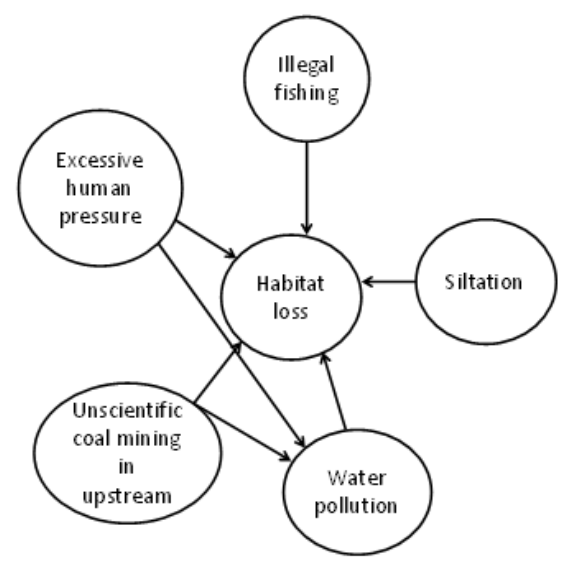

Fig. 3. Major interactive causes for depletion of mohashol in Someshwari river.

In recent years Someshwari river is under excessive human pressure for livelihood (Fig. 4). Coal particles, sand and fish are being collected from this river all the year round. The coal particles available in the Someshwari may be resulted from the coal mining of Nongalbibra and Siju area located on the river bank of Simsung in Meghalaya, India. Moreover, white clay collected from Bijoypur is dumped on the bank of river and exported through mechanized boat from which oil seepage occurs and pollutes the water. Someshwari is also used for transporting white clay from Cullagora to Jaria through mechanized boat from which oil seepage occurs and pollutes the water. During rainy season local fishers set one kind of fishing gear locally called Khara jal to catch fish which is illegal and prohibited according to "East Bengal Protection and Conservation of Fish Act, 1950". They do not bother whether the fish is gravid or not. During early flash flood in May-June, this gear is set at several points of Someshwari river and operated throughout the rainy season (Fig. 5). Fish are compelled to move unidirectionally inside the gear which is set behind the bamboo structure and uplifted every 10-15 minutes interval for harvesting the fish. On the other hand, in winter, the Someshwari dries up to a level where it is only recognized as narrow ditch and paddy fields. 

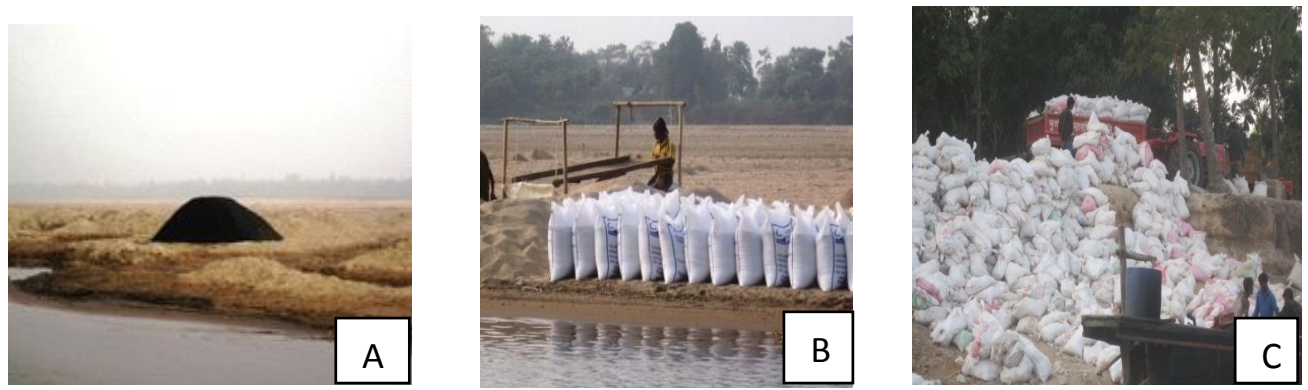

Fig. 4. Human activities in the Someshwari river. Collected and dumped coal (A), collected and packed sand (B), and dumping of white clay bags for loading in the engine boat for export (C).
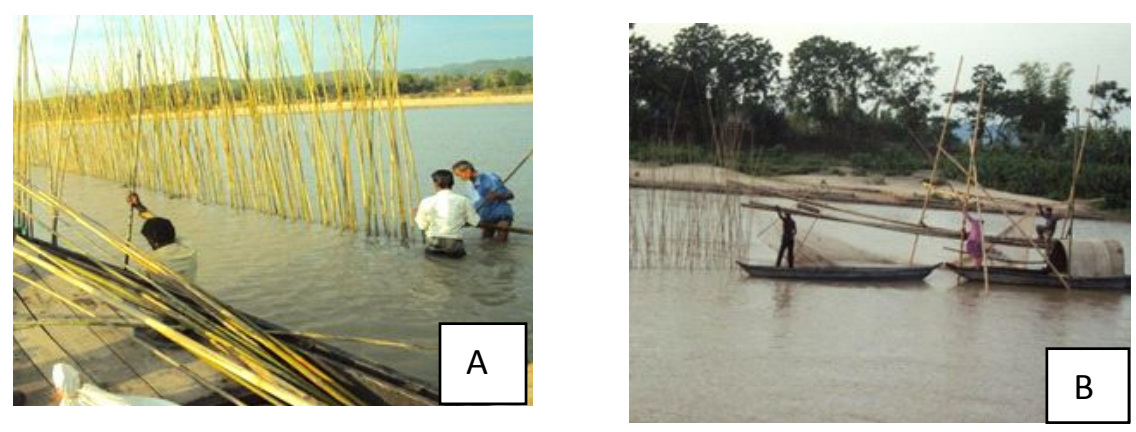

Fig. 5. Installation (A) and Operation (B) of Khara jal in Someshwari river.

Besides these, in the last few decades, the ecology of the Indian part of Someshwari named Simsung became threatened by large scale environmental degradation caused by extensive deforestation, over- exploitation of natural resources and other anthropogenic activities coupled with unprecedented rise in human population (Sarma et al. 2009). In recent years, unscientific coal mining in the Meghalaya region has further aggravated the problem and due to this, more than $100 \mathrm{~km}$ stretch (from Baghmara to William Nagar) of the Simsung river (Fig. 6) is severely affected by Acid Mine Drainage (AMD) (Mallik et al. 2015), that principally led to water quality degradation and decline in fish biodiversity in the water bodies of the mining area (Mylliemngap and Ramanujam 2011). Due to severe AMD effect, no fish catch was recorded in Nongalbibra during August 2013 to December 2014 and a few T. putitora was caught by cast netting in the Simsung of Siju area where coal mining was occurred. On the other hand, both $T$. tor and T. putitora were caught from the Simsung of Willium Nagar (mining free area) by using the same net. Furthermore, no catch of both types of mohashol was reported at the same time in the area of the Simsung river of Baghmara which is the receiving point of AMD (Mallik et al. 2015). So, it is evident that due to unscientific coal mining, abundance of mohashol has been declining drastically in the areas of Simsung and Baghmara. Therefore, intensive research on water quality parameters at both Baghmara (Meghalaya) and Durgapur (Bangladesh) point is essential to take proper steps for conservation of mohashol in Bangladesh. 
According to the local fishers on the bank of Simsang river, about 10-20 years ago mahseers and electric fish weighing about 10 to $25 \mathrm{~kg}$ were used to be caught from the area but at present the size of the fish species as well as catch per unit effort has been reduced to the minimum. Fishing using herbal poison is also one of the causes for depletion of fish diversity (Sarma et al. 2009). As Someshwari is a transboundary river between Bangladesh and India and it has entered in Bangladesh through Baghmara, a receiver of AMD; the mohashol fishery of Someshwari river has been significantly decreased due to degradation of habitat and breeding ground and led them to become critically endangered.

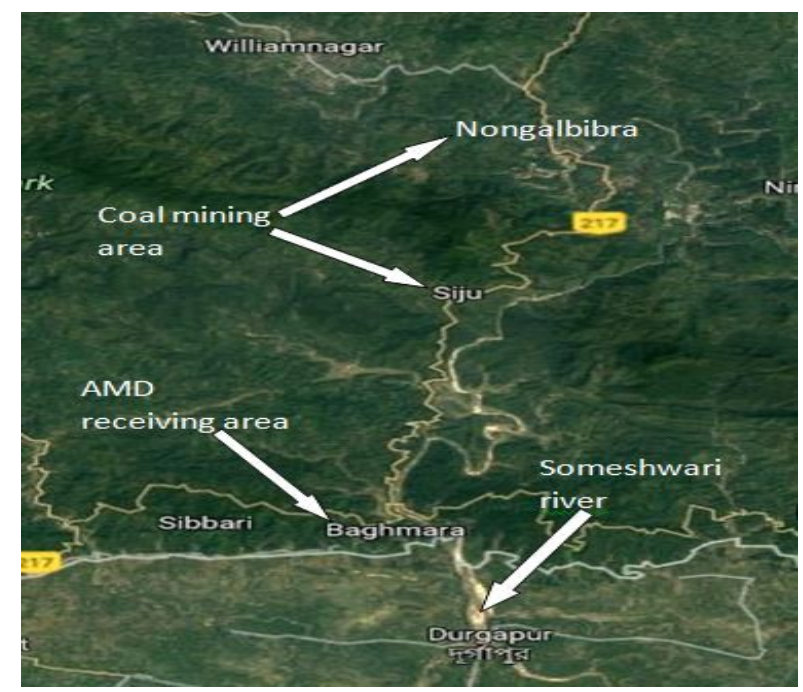

Fig. 6. Coal mining area of Someshwari river in Meghalaya (source: Google earth).

\section{Conservation attempts}

Every single flora and fauna have specific role to its respective ecosystem. So, it is very important to conserve every species in their respective ecosystem for maintaining a sustainable biodiversity. In Bangladesh, the freshwater fish diversity is enormous but very little time and effort has been invested for their conservation. Biodiversity conservation is a prime issue worldwide in the context of climate change, and considerable attempts are being undertaken for conservation of many endangered species using pragmatic management and conservation measures. Scientists from the Department of Fisheries Biology and Genetics, Bangladesh Agricultural University (BAU) has brought mohashol under the purview of research for the first time in 2010 with the funding of BARC-World Bank supported 'Sponsored Public Goods Research' (SPGR) project for domestication and breeding. They have got some successes in respect of rearing in captivity with supplementary pelleted feed (Mollah, 2013). After ending the SPGR project, the research on captive rearing, genetic characterization and breeding of mohashol was continued with the funding of World Bank-UGC funded HEQEP-AIF project. The fish grew well with supplementary feeds (Kabir et al. 2018) in ponds and the maturity and breeding season were identified through histological study of gonads (Kabir 2021). Some of the 
fish attained maturity in the captivity and produced milt that provided an opportunity to conduct some preliminary works on cryopreservation of sperm (Sarder et al. 2017). Genetic characterization of the fish stock was also done using a set of DNA microsatellite markers (Sarder et al. 2018). Presently, a research project on broodstock development, induced breeding and cryogenic sperm banking of Tor tor funded by the Ministry of Education, is being conducted by the scientists from BAU. Though the scientists from the university took initiatives to conserve the mohashol, the Department of Fisheries (DoF), Government of Bangladesh should take main responsibility to protect the critically endangered mohashol as well as other endangered fish species. In the last few years, DoF has taken some conservation measures through establishing fish sanctuaries in different rivers and other waterbodies (Kaiya et al. 2005, Barman and Kaium 2016), but these are not enough to conserve the threatened and endangered fish species. In the year 1991, a contingent of T. putitora was introduced in Bangladesh from Nepal for stock enhancement (Hussain and Mazid 2001). The artificial breeding technique of $T$. putitora has been developed and seed production of the species is being practiced by the government and some private hatcheries but the fry rearing technique of this species has not been standardized yet. On the other hand, the artificial breeding technique of $T$. tor could not develop yet. Considering the present status of $T$. tor, it is essential to conserve the critically endangered Tor tor with due attention from the concerned authority.

\section{Conclusions}

Considering the physical scenario of Someshwari river and production (capture) trend of $T$. tor during the last 15 years, it is likely that the species may go extinct unless an empirical method is undertaken. Since in-situ conservation through restoration of habitat of $T$. tor is not possible within a very short time, ex-situ conservation could be an immediate option for conserving the valuable, glorious and delicious mohashol. Development of induced breeding technique and cryogenic gene bank through cryopreservation of sperm can be the effective tools in this regard. Moreover, political will of national and regional authorities for conservation of $T$. tor and the participation of local communities in this conservation process must be ensured.

\section{Literature Cited}

Alam, A.K.M.K., 2004. The Someshwari River (Bangladesh) response to active tectonics. Abstract Volume; $4^{\text {th }}$ Nepal Geological Congress, Nepal Geological Society, Katmandu.

Babel, M.S. and S.M. Wahid, 2008. Freshwater under Threat South Asia: Vulnerability Assessment of Freshwater Resources to Environmental Change. United Nations Environmental Programme (UNEP), Asian Institute of Technology, 29p.

Barman, B.K. and M.A. Kaium, 2016. Importance of sanctuary for enhancement of fish production and biodiversity: Baikka Beel perspective. National Fish Week Compendium, Department of Fisheries, Ministry of Fisheries and Livestock, Bangladesh, pp. 51-53.

Chakraborty, B.K. and M.J.A. Mirza, 2010. Status of Aquatic Resources in Someshwari River in Northern Bangladesh. Asian Fish. Sci., 23: 174-193.

Chen, Z. and J. Yang, 2004. A new species of genus Tor from Yunan China (Teleostei: Cyprinidae). Environ. Biol. Fish., 70: 185-191.

David, D.D., 2012. Threats to freshwater biodiversity globally and in the Indo-Burma Biodiversity Hotspot. In: Dispersal: 13-28 (D.J. Allen, K.G. Smith, and W.R.T. Darwall Compilers). IUCN, Cambridge, UK and Gland, Switzerland. 
Dudgeon, D., 2012. Threats to Freshwater Biodiversity Globally and in the Indo-Burma Biodiversity Hotspot. (D.J. Allen, K.G. Smith, and W.R.T. Darwall Compilers). The Status and Distribution of Freshwater Biodiversity. Published by IUCN, Cambridge, UK and Gland, Switzerland, 158p.

Dudgeon, D., A.H. Arthington, M.O. Gessner, Z. Kawabata, D. Knowler, C. Lévêque, R.J. Naiman, A.H. Prieur-Richard, D. Soto, M.L.J. Stiassny and C.A. Sullivan, 2006. Freshwater biodiversity: importance, threats, status and conservation challenges. Biol. Reviews, 81: 163-182.

Fishbase, 2014. "Tor tor (Hamilton, 1822)" https://www.fishbase.se/summary/tor-tor.html.

Gozlan, R.E., S. St-Hilaire, S.W. Feist, P. Martin and M.L. Kent, 2005. Biodiversity: disease threat to European fish. Nature, 435(7045): 1046, doi: 10.1038/4351046a

Haque, M.Z., S.C. Mahata, M.Z. Ali, M.G. Hussain and M. A. Mazid, 1995. Seed production of Himalayan mahseer, Tor putitora (Ham.) in Bangladesh. J. Asiat. Soc. Bangladesh, Sci., 21: 279282.

Hossain, M.A.R., 2014. Habitat and fish diversity: Bangladesh perspective. In: Dispersal: 1-26 (M.A. Wahab, M.S. Shah, M.A.R. Hossain, B.K. Barman and M.E. Hoq, (Eds.). Bangladesh Fisheries Research Forum, Dhaka, Bangladesh.

Hussain, M.G. and M.A. Mazid, 2001.Genetic improvement and conservation of carp species in Bangladesh. Bangladesh Fisheries Research Institute and International Center for Living Aquatic Resources Management (ICLARM), Bangladesh.

Ingram, B.A., S. Sungan, G. Gooley, S.Y. Sim, D. Tinggi and S.S. De Silva, 2005. Induced spawning, larval development and rearing of two indigenous Malaysian mahseer, Tor tembroides and $T$. douronensis. Aquacult. Res., 136: 1001-1014.

IUCN Bangladesh, 2015. Red List of Bangladesh: A Brief on Assessment Result 2015. IUCN, International Union for Conservation of Nature, Bangladesh Country Office, Dhaka, Bangladesh.

Jha, B.R., A. Rayamajhi, N. Dahanukar, A. Harrison and A. Pinder, 2018. Tor putitora. The IUCN Red Listof Threatened Species 2018 http://dx.doi.org/10.2305/IUCN. UK.2018-2.RLTS. T126319882A126322226.en

Kabir, M.S.U., 2021. Study of morphometry, genetic structure and gonadal maturation of critically endangered mohashol Tor tor and its ex-situ conservation. PhD dissertation. Department of Fisheries Biology and Genetics, Bangladesh Agricultural University, Mymensingh.

Kabir, M.S.U., F. Arefin, M.M. Rahman, M.R.I. Sarder and M.F.A. Mollah, 2018. Domestication of red fin mahseer (Tor tor) with supplementary feeds in captive condition in Bangladesh. J. Bangladesh Agril. Univ., 16(3): 533-538.

Kaiya, M.K.U., M.Z. Islam and M.M. Kadir, 2005. Establishment of fish sanctuary to conserve and enhance biodiversity. National Fish Week Compendium, Department of Fisheries, Ministry of Fisheries and Livestock, Bangladesh, pp. 81-85.

Mallik, S.K., D. Sarma, D. Sarma and N. Shahi, 2015. Acid mine drainage, a potential threat to fish fauna of Simsung River, Meghalaya. Curr. Sci., 109: 687-690.

McGrouther, M., 2006. "Fish scales". Ichthyology at the Australian Museum: Collections, Databases and the Web. Proceedings of the 7th and 8th Symposia on Collection Building and Natural History Studies in Asia and the Pacific Rim, Tomida et al. (eds) National Science Museum Monographs, 34: $103-116$.

Menon, A.G.K., 1992. Taxonomy of the Mahseer fishes of Genus Tor Gray with description of new species from Deccan. J. Bombay Nat. Hist., Soc., 89: 210-228.

Mollah, M.F.A., 2013. Gene banking of improved broodstocks of Indian major carps (catla, rohu and mrigal) and development of breeding technique of three threatened species (mohashol, bagair and baim). Final Report submitted to PIU-BARC, BARC Complex, Farmgate, Dhaka-1215

Mylliemngap, B.K. and S.N. Ramanujam, 2011. Icthyodiversity in the Coal Mining and adjacent NonCoal Mining Drainages of Jaintia Hills, India. Asian Fish. Sci., 24: 177-185.

$\mathrm{Ng}, \mathrm{C} . \mathrm{K} ., 2004$. King of the Rivers: Mahseer in Malysia and the Region. Inter Sea Fishery (M) SDN. BHD., Kuala Lumpur, Malaysia. 
Ogale, S.N., 2002. Mahseer breeding and conservation and possibilities of commercial culture. The Indian experience. In T. Petr and D.B. Swar (eds.) Cold Water Fisheries in the Trans-Himalayan Countries. FAO Fish. Tech. Pap. 431, 193-212.

Rahman, A.K.A., 1989. Freshwater fishes of Bangladesh. The Zoological Society of Bangladesh, Department of Zoology, University of Dhaka, Dhaka.

Roberts, T.R., 1993. The freshwater fishes of Java, as observed by Kuhl and Van Hasselt in 1820-23. Zoologische Verhandelingen, 285: 1-94.

Shrestha, T.K., 1990. Rare fishes of Himalayan waters of Nepal. J. Fish Biol., 37: 213-216.

Shrestha, T.K., 1997. Prospects of propagation of mahseer in Phewa lake of Pokhara valley. The Mahseer, pp. 70-71.

Sarder, M.R.I., N.B. Ryhan, M.S.U. Kabir, and M.F.A. Mollah, 2017. Cryopreservation of sperm of critically endangered mohashol, Tor tor (Hamilton) for ex-situ conservation presented at $4^{\text {th }}$ International Conference on Fisheries and Aquaculture in Colombo, Sri Lanka from 24-26th August, 2017.

Sarder, M.R.I., M.S.U. Kabir, M.M. Bella, M.M. Rahman and M.F.A. Mollah, 2018. Assessment of genetic variation of critically endangered Mohashol, Tor tor (Hamilton) of Someswari river by microsatellite DNA markers for stock assessment and conservation. Poster presentation at $10^{\text {th }}$ Asian Federation of Biotechnology held at Nabab Nawab Ali Chowdhury Senate Bhaban, University of Dhaka on 27-29 January, 2018.

Sarma, D., P.C. Mahanta, D. Sarma and A. Dutta, 2009. Coalmines Degraded Ichthyofaunal Diversity of Simsung River, Meghalaya. A report on climate change. Bulletin No - 15. Directorate of Coldwater Fisheries Research, Indian Council of Agricultural Research, Bhimtal-263 136, Nainital, Uttarakhand, India.

Stone, R., 2007. The Last of the Leviathans. Science, 316: 1684-1688.

Strayer, D.L. and D. Dudgeon, 2010. Freshwater biodiversity conservation: recent progress and future challenges. J. North Am. Benthol. Soc., 29: 344-358.

Vorosmarty, C.J., P.B. McIntyre, M.O. Gessner, D. Dudgeon, A. Prusevich, P. Green, S. Glidden, S.E. Bunn, C.A. Sullivan, C.R. Lierman, and P.M. Davies, 2010. Global threats to human water security and river biodiversity. Nature, 467: 555-561.

(Manuscript received: 14 April 2021) 